\title{
CONTRIBUTION OF ANTHROPOGENIC AND NATURAL SOURCES TO THE LEVELS OF TRACE ELEMENTS IN TWO COSTAL SITES IN CAMPECHE, MEXICO
}

\author{
R.M. CERÓN-BRETÓN ${ }^{1}$, J.G. CERÓN-BRETÓN ${ }^{1}$, J.J. GUERRA-SANTOS ${ }^{1}$, E. NÚÑEZ-LARA ${ }^{1}$ \& \\ M. MURIEL-GARCÍA ${ }^{2}$ \\ ${ }^{1}$ Universidad Autónoma del Carmen (UNACAR), Mexico. \\ ${ }^{2}$ Instituto Mexicano del Petróleo (IMP), Mexico.
}

\begin{abstract}
The influence of anthropogenic and geochemical sources on trace metal levels in wet deposition was studied in two coastal sites - Isla del Carmen and San Antonio-Cardenas - both located in the State of Campeche. Simultaneous samplings of precipitation were carried out by automatic samplers from June 1 to October 31, 2004. A total of 52 samples were collected to determine trace metals ( $\mathrm{Al}, \mathrm{Fe}, \mathrm{Mn}, \mathrm{Cu}, \mathrm{Zn}, \mathrm{Pb}$ and Ni). A mean $\mathrm{pH}$ value of 4.64 was found for San Antonio-Cardenas, whereas in Isla del Carmen this value was 5.38, indicating levels of acidity in rainwater in San Antonio-Cardenas while Isla del Carmen showed a natural buffer capacity to neutralize the acidity. The influence of the crustal was evident in both sampling sites, specifically for Al, $\mathrm{Fe}$ and $\mathrm{Mn}$. In both sites, high percentages of dissolved fractions were found for $\mathrm{Cu}, \mathrm{Pb}, \mathrm{Zn}$ and Ni. However, these percentages were more significant in San Antonio-Cardenas, suggesting that these trace elements had an anthropogenic source.

Keywords: acid rain, anthropogenic sources, chemical composition, coastal sites, crustal fraction, enrichment factors, marine fraction, rainwater, trace elements, wet deposition.
\end{abstract}

\section{INTRODUCTION}

Wet deposition is important in coastal zones because of its episodic nature and partial transference in solution to receptor, enhancing biological interactions [1]. For this reason, acid compounds and trace metals present in wet deposition may cause an eventual significant damage to the environment (superficial water, vegetation, fauna, and so on). Therefore, it is necessary to discuss the origin of trace metals incorporated to the environment as a consequence of the atmospheric deposition processes [2].

The chemistry of trace elements in the atmosphere is influenced by different sources of gases and aerosols, and some elements such as heavy metals have different sources as natural emissions (biogenic), geochemical emissions (marine aerosol and crustal) or anthropogenic emissions (combustion processes) [3-8].

A great percentage of metals are deposited around the emission source, however, those aerosols that show lower sedimentation rates may be easily transported and transferred by the wind action and finally deposited in distant places from the emission point [9]. Trace metals derived from geochemical sources may contribute in a significant way to the total content of metals in the rainwater of a specific site $[10,11]$. However, trace elements may show a relative enrichment to their geochemical source, this enrichment being a good indicator of pollution [12, 13], which is expressed as an enrichment factor $(\mathrm{EF})$ by using a tracer element $(\mathrm{Na}+$ or $\mathrm{Cl}$ - for marine aerosol, and $\mathrm{Al}$ for crustal). When EF is closer to unity, it means that the element was originated from the evaluated source (marine aerosol or crustal), whereas an EF greater than unity means that there were significant contributions of other sources, including anthropogenic ones.

Good correlations between trace metals suggest common sources. Elements such as $\mathrm{Cd}, \mathrm{Ni}, \mathrm{Cr}$, $\mathrm{Pb}, \mathrm{Cu}$ and $\mathrm{Zn}$ are associated with anthropogenic activities, because they can be incorporated to rainwater in dissolved form at $\mathrm{pH}$ values lower than 5.0 [4, 14], whereas Fe and $\mathrm{Mn}$ do not correlate 
with the rest of the metals due to their geochemical origin [2, 15-19]. Generally, metals from high-temperature processes are loosely bound to aerosol surface, and therefore have greater solubility in rainwater and seawater than metals bound within the aluminosilicate lattices of mineral aerosol particles from crustal weathering [11, 20, 21]. Zinc is generally present in dissolved form (originated from a non-crustal source), whereas $\mathrm{Fe}$ and $\mathrm{Al}$ are not easily dissolved (originated from crustal particles).

This work reports only the dissolved fraction and the total content of trace metals in wet deposition in two coastal sites in Campeche, Mexico (San Antonio-Cardenas and Isla del Carmen), and discusses their origin by using trace elements, enrichment factors and the prevailing meteorology during the sampling campaigns. Ion levels and their sources in these two coastal sites were reported and discussed in a previous paper [14].

\subsection{Study area}

\section{EXPERIMENTAL}

The region surrounding the San Antonio-Cardenas site has showed an accelerated development associated with the oil industry. Within this zone there is a recompression plant where sour gas is received from offshore platforms and sent to the petrochemical industries for processing. The recompression plant has a safety system with four sour gas burners that deliver pollutants to the atmosphere, mainly $\mathrm{SO}_{2}$, particles and hydrocarbons [22].

San Antonio-Cardenas is located at $18^{\circ} 22^{\prime} 12^{\prime \prime} \mathrm{N}$ and $92^{\circ} 07^{\prime} 47^{\prime \prime} \mathrm{W}$, about $40 \mathrm{~km}$ from Isla del Carmen and $10 \mathrm{~km}$ from Atasta recompression plant. Isla del Carmen is located at $18^{\circ} 41^{\prime} 59^{\prime \prime} \mathrm{N}$ and $91^{\circ} 38^{\prime} 24^{\prime \prime} \mathrm{W}$. According to the Köeppen classification [19], the climate in both sites is sub-humid warm with summer rains. The average annual rainfall is $1393.1 \mathrm{~mm}$ and the average annual temperature is $27.2^{\circ} \mathrm{C}$. Winds prevail from NE and SE all year around and blow at an average speed of $1.4 \mathrm{~m} \mathrm{~s}^{-1}$ [19]. Both sites are within the Natural Reserved and Protected Area named 'Laguna de Terminos' (Fig. 1).

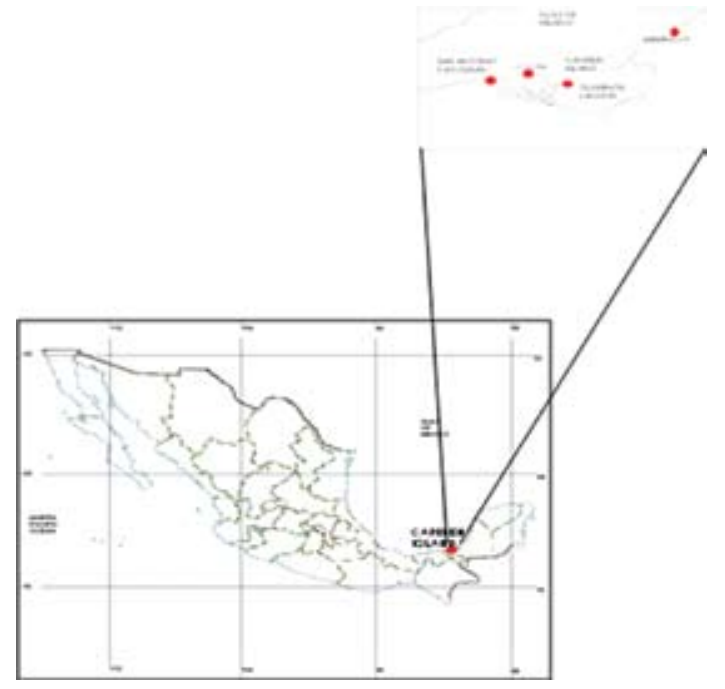

Figure 1: Location of sampling sites. 


\subsection{Rain sampling}

Wet precipitation samples were simultaneously collected in both sites from June 1 to October 31 in 2004. Two automatic wet/dry precipitation collectors were used (Tisch Environmental Inc, TE-78-100 model, USA). One of them was located over the roof of the Chemistry School Building in UNACAR (about $3 \mathrm{~m}$ over the soil), and the other was located over the roof of the Campeche Technological University (about 3.5 m over the soil) in Isla del Carmen and San Antonio-Cardenas, respectively.

Samples were preserved by acidification at a $\mathrm{pH}<2.0$ with $\mathrm{HNO}_{3}$ and stored at $4{ }^{\circ} \mathrm{C}$ for further chemical analysis, according the recommended criteria by Ahlers [23], assuring the stability of the samples for 6 months. The minimal sampling volume was $500 \mathrm{ml}$, and samples with visible contamination (leaves, insects, dust and so on) were rejected.

\subsection{Chemical analysis}

Before preserving samples, the $\mathrm{pH}$ value was determined using a pHmeter (HACH EC10) calibrated by means of buffer solutions (Termo-Orion) at $\mathrm{pH} \mathrm{4.0} \mathrm{and} \mathrm{7.0.} \mathrm{All} \mathrm{plasticware} \mathrm{and}$ glassware used to prepare standard solutions, for samples digestion and for chemical analysis (buckets, funnels, filtration apparatus, tubing and bottles) were rigorously washed, brushed and rinsed with distillated water. All material was completely immersed during $24 \mathrm{~h}$, in a $20 \%$ ultrapure nitric acid bath (J.T. Baker, AA grade), then rinsed several times with deionized water type I (Hycel) and sealed into double plastic bags. Before sampling, all material was again rinsed with deionized water.

Standard solutions were prepared by dilution from certified standards (J.T. Baker). Each collected sample was divided in two aliquots of $250 \mathrm{ml}$ : the first one was used to determine dissolved metals, and the other to analyze total metals. To determine the dissolved fraction, samples were filtered using membranes of $0.22 \mu \mathrm{m}$ (Phenomenex ${ }^{\circledR}$ ) and a vacuum filtration apparatus (Kontes ultraware $\left.{ }^{\circledR}\right)$. To determine the total content of metals, the samples were not filtered. In both cases, digestion process was carried out in Teflon ${ }^{\circledR}$ closed flasks (Cole-Parmer) of $100 \mathrm{ml}$, using as energy source an autoclave equipment. The chemical elements $\mathrm{Fe}, \mathrm{Mn}, \mathrm{Ni}, \mathrm{Cu}, \mathrm{Zn}, \mathrm{Al}$ and $\mathrm{Pb}$ were analyzed with graphite furnace atomic absorption spectrometer (GBC Avanta) [24-32].

\subsection{Trajectories}

The Southeast of Mexico shows two well-defined climatic periods, a dry season (from November to May) and a wet season (from June to October), for this reason, in this study the sampling campaigns were carried out during the rainy season and therefore, it was not possible to assess seasonal trends. Backward trajectories were calculated for all rain events during the sampling period, and were used to trace the origin of the air masses for the rain events. The calculation of individual trajectories for each rain event was made $48 \mathrm{~h}$ before the event began using NOAA HYSPLIT (Hybrid Single Particle Lagrangian Integrated). From backward trajectories calculated, it was observed that prevailing winds came from the NE in both sampling sites [33].

\subsection{Statistical analysis}

Pearson's correlation analysis was applied to test the relationship among the total trace metal concentrations for each sampling site. Factor analysis was applied to determine the factors underlying 
the interactions among surveyed species. ANOVA (GLM) was performed to test the difference between each element. Means comparison was also performed by using the average concentration values of the trace metals as well as the $\mathrm{pH}$ value. The calculations were carried out using SAS 8.0 software [34].

Principal component analysis (PCA), a linear method for multivariate ordination, was used to visualize the relationship among trace elements at each sampling site, focused on the interelements correlation coefficients. The sample points and variables together form a biplot that display approximately inter-variables correlations. Three PCAs were performed in order to identify: (i) the main factors explaining the variation of the measured elements at both studied sites (inter-sites variation), (ii) those significant factors at Isla del Carmen and (iii) at San AntonioCardenas (intra-site variation). ANOVA tests by permutation were performed in order to test the significance of the factors to explain those variations. Analyses were carried out using R statistical project.

\section{$3.1 \mathrm{Bulk} /$ wet precipitation}

\section{RESULTS AND DISCUSSION}

Table 1 shows the minimum, maximum and mean concentration values $\left(\mu \mathrm{g} \mathrm{l}^{-1}\right)$, and standard deviation for $\mathrm{pH}$ and trace metals in rainwater, respectively, collected in both sampling sites.

In wet deposition studies, it is common to carry out the chemical characterization by determination of ions and trace elements levels. In a previous paper [14], ionic abundance was reported for San Antonio-Cardenas and Isla del Carmen. The most abundant cations in both sites were $\mathrm{Na}^{+}$and $\mathrm{Ca}^{2+}$, probably due to the influence of marine aerosol and crust (because calcareous soils are abundant in Yucatan Peninsula). Agricultural practices are not present in any of the two sites, for this reason $\mathrm{NH}_{4}{ }^{+}$levels were very low. The most abundant anions in two locations were $\mathrm{Cl}^{-}$(due to the influence

Table 1: Minimum and maximum values, mean and standard deviation for $\mathrm{pH}$ and trace metals in rainwater collected in San Antonio-Cardenas and Isla del Carmen, from June 1 to October $31,2004$.

\begin{tabular}{lrrrrrrrr}
\hline & & \multicolumn{7}{c}{ Trace metals concentrations $\left(\mu \mathrm{g} \mathrm{l}^{-1}\right)$} \\
\cline { 3 - 9 } Values & $\mathrm{pH}$ & $\mathrm{Al}$ & $\mathrm{Fe}$ & $\mathrm{Mn}$ & $\mathrm{Cu}$ & $\mathrm{Zn}$ & $\mathrm{Pb}$ & $\mathrm{Ni}$ \\
\hline San Antonio-Cardenas & & & & & & & & \\
Media & 4.64 & 19.03 & 10.74 & 6.74 & 30.90 & 44.81 & 10.18 & 10.62 \\
Maximum & 6.27 & 32.00 & 22.00 & 14.00 & 58.00 & 75.85 & 18.30 & 16.40 \\
Minimum & 3.01 & 3.00 & 2.00 & 2.70 & 5.40 & 7.83 & 4.32 & 6.54 \\
Standard deviation & 0.76 & 8.64 & 6.40 & 3.70 & 14.28 & 20.05 & 3.24 & 2.35 \\
Isla Del Carmen & & & & & & & & \\
Media & 5.37 & 28.77 & 19.66 & 10.29 & 25.05 & 39.85 & 4.88 & 6.55 \\
Maximum & 6.91 & 38.40 & 26.48 & 16.50 & 38.67 & 64.23 & 8.32 & 12.37 \\
Minimum & 2.98 & 11.41 & 7.61 & 2.82 & 13.16 & 15.54 & 1.97 & 1.78 \\
Standard deviation & 1.06 & 8.10 & 5.66 & 4.41 & 7.94 & 17.05 & 1.76 & 3.27 \\
\hline
\end{tabular}


Table 2: Dissolved fraction and insoluble fraction of trace elements in both sampling sites.

\begin{tabular}{lrrrrrrr}
\hline & $\mathrm{Al}$ & $\mathrm{Fe}$ & $\mathrm{Mn}$ & $\mathrm{Cu}$ & $\mathrm{Zn}$ & $\mathrm{Pb}$ & $\mathrm{Ni}$ \\
\hline San Antonio-Cardenas & & & & & & & \\
Soluble fraction (\%) & 10.00 & 17.97 & 13.05 & 88.99 & 92.99 & 97.05 & 90.96 \\
Insoluble fraction (\%) & 90.00 & 82.03 & 86.95 & 11.01 & 7.01 & 2.95 & 9.04 \\
Isla del Carmen & & & & & & & \\
Soluble fraction (\%) & 6.50 & 11.70 & 10.20 & 79.00 & 85.70 & 99.10 & 86.87 \\
Insoluble fraction (\%) & 93.50 & 88.30 & 89.80 & 21.00 & 14.30 & 0.90 & 13.13 \\
\hline
\end{tabular}

of sea-salt aerosol) and enriched $\mathrm{SO}_{4}{ }^{2-}$; the sulphate in excess suggests that there is influence of sources different from marine aerosol, mainly in San Antonio-Cardenas.

The main chemical elements generally are divided in two groups, depending on if they are present in the dissolved form or in the insoluble form. In rainwater, $\mathrm{Al}, \mathrm{Fe}$ and $\mathrm{Mn}$ are generally within the group of insoluble elements, whose sources are insoluble particles from the crustal, mainly aluminosilicates [35]. The second group comprises elements with an anthropogenic origin such as $\mathrm{Cu}, \mathrm{Pb}, \mathrm{Zn}$ and $\mathrm{Ni}$. In this study, a significant fraction of $\mathrm{Al}, \mathrm{Fe}$ and $\mathrm{Mn}$ is present in an insoluble form (Table 2) according to previous reports $[11,16,17,21,36]$.

Trace elements present in crustal aerosols are less soluble than other aerosols (biogenic, marine or anthropogenic), thus the elemental phase distribution decreases as the crustal apportionment in precipitation increases. The crustal influence in mineralization process of rainwater in both sampling sites was clearly observed, specifically for $\mathrm{Al}, \mathrm{Fe}$ and $\mathrm{Mn}$.

In both sites, $\mathrm{Cu}, \mathrm{Pb}, \mathrm{Zn}$ and $\mathrm{Ni}$ showed significant soluble fractions (Table 2), thus it can be inferred that they had their origin in anthropogenic sources, which is in agreement with reports in similar studies [11, 16, 17, 21,36].

Due to the uptake of atmospheric $\mathrm{CO}_{2}$ that dissolves in water until it reaches equilibrium, even in remote sites, rainwater has a $\mathrm{pH}$ value approaching to 5.6. $\mathrm{pH}$ values in rainwater between 5 and 5.6 suggest that the site has enough buffer capacity to neutralize the acidity, whereas, $\mathrm{pH}$ values lower than 5 indicate an acidity condition. The mean value of $\mathrm{pH}$ found in rainwater of San AntonioCardenas was 4.64 , and $65.38 \%$ of the samples showed $\mathrm{pH}$ values lower than 5, suggesting that this site is probably impacted by anthropogenic sources. On the other hand, the mean $\mathrm{pH}$ value found in the rainwater of Isla del Carmen was 5.38 and $34.61 \%$ of the samples showed $\mathrm{pH}$ values lower than 5 , therefore, Isla del Carmen is a site less impacted by anthropogenic sources.

\subsection{Statistical analysis results}

The origin of elements in rainwater can be inferred by correlations between elements and let us identify common sources of atmospheric species or similar removal processes during the removal mechanisms in clouds (Rain-out and Wash-out) [35, 37].

From Tables 2 and 3, it can be observed that some elements were present in a great proportion in insoluble form (Al, Fe and $\mathrm{Mn}$ ), showing significant correlations with each other in both sampling sites $(\alpha=0.05)$, and suggesting that they have their origin in common sources, probably from soil particles or from the crustal. Likewise, the remaining elements were present in a greater proportion in a dissolved form $(\mathrm{Cu}, \mathrm{Zn}, \mathrm{Pb}$ and $\mathrm{Ni})$ correlating in a significant way in both sites $(\alpha=0.05)$, 
Table 3: Pearson's correlation matrix among trace elements and $\mathrm{pH}$ at Isla del Carmen and San Antonio-Cardenas (from June 1 to October 31, 2004).

\begin{tabular}{|c|c|c|c|c|c|c|c|c|}
\hline & $\mathrm{pH}$ & $\mathrm{Al}$ & $\mathrm{Fe}$ & $\mathrm{Mn}$ & $\mathrm{Cu}$ & $\mathrm{Zn}$ & $\mathrm{Pb}$ & $\mathrm{Ni}$ \\
\hline \multicolumn{9}{|c|}{ Isla del Carmen } \\
\hline $\mathrm{pH}$ & 1.0000 & 0.9580 & 0.9289 & 0.9102 & -0.7099 & -0.7386 & -0.8363 & -0.8632 \\
\hline $\mathrm{Al}$ & & 1.0000 & 0.9573 & 0.9242 & -0.7657 & -0.8782 & -0.8443 & -0.8608 \\
\hline $\mathrm{Fe}$ & & & 1.0000 & 0.9081 & -0.8186 & -0.8798 & -0.8806 & -0.8948 \\
\hline Mn & & & & 1.0000 & -0.8030 & -0.9231 & -0.8724 & -0.8994 \\
\hline $\mathrm{Cu}$ & & & & & 1.0000 & 0.8826 & 0.8650 & 0.8775 \\
\hline $\mathrm{Zn}$ & & & & & & 1.0000 & 0.9299 & 0.9035 \\
\hline $\mathrm{Pb}$ & & & & & & & 1.0000 & 0.9236 \\
\hline $\mathrm{Ni}$ & & & & & & & & 1.0000 \\
\hline \multicolumn{9}{|c|}{ San Antonio-Cardenas } \\
\hline $\mathrm{pH}$ & 1.0000 & 0.9299 & 0.9503 & 0.8954 & -0.9204 & -0.9220 & -0.9272 & -0.8272 \\
\hline $\mathrm{Al}$ & & 1.0000 & 0.9179 & 0.8120 & -0.8861 & -0.8874 & -0.8954 & -0.7665 \\
\hline $\mathrm{Fe}$ & & & 1.0000 & 0.9403 & -0.9265 & -0.9256 & -0.8641 & -0.7708 \\
\hline $\mathrm{Mn}$ & & & & 1.0000 & -0.9271 & -0.9123 & -0.8110 & -0.7730 \\
\hline $\mathrm{Cu}$ & & & & & 1.0000 & 0.9734 & 0.9443 & 0.8481 \\
\hline $\mathrm{Zn}$ & & & & & & 1.0000 & 0.9450 & 0.8015 \\
\hline $\mathrm{Pb}$ & & & & & & & 1.0000 & 0.8394 \\
\hline $\mathrm{Ni}$ & & & & & & & & 1.0000 \\
\hline
\end{tabular}

it suggests that they had common sources (anthropogenic). These results match with other studies reported in the literature $[11,16-18,21,35,36]$.

Speed and wind direction influences the chemical composition of the rainwater, thus, depending on wind direction, marine, continental, local or regional sources located upwind of the sampling site could influence the content of trace elements in the rainwater.

According to Table 3, there is a high correlation among $\mathrm{pH}$ and $\mathrm{Al}, \mathrm{Fe}$ and $\mathrm{Mn}$; in both sampling sites (significant level $0.01 \%$ ) a strong correlation among them can be observed. Whereas these elements are negatively correlated with $\mathrm{Cu}, \mathrm{Zn}, \mathrm{Pb}$ and $\mathrm{Ni}$, this is due to the fact that this group of elements can be originated in anthropogenic activities while the first group is associated with the crustal. $\mathrm{Cu}, \mathrm{Zn}, \mathrm{Pb}$ and $\mathrm{Ni}$ are correlated among themselves in a high significance level but they have a negative correlation with $\mathrm{pH}, \mathrm{Fe}, \mathrm{Mn}$ and $\mathrm{Al}$. The analysis of variance revealed that a significance level of $\alpha=0.05$ (Table 4) excepting Zn, data obtained for most variables was statistically significant for both sites during the rainy season of 2004.

According to Table 5, it can be observed that excepting $\mathrm{Zn}$, the mean values of all elements showed significant difference between the two sampling sites including $\mathrm{pH}$. Principal component analysis showed a common pattern in the intra-sites variation of trace elements. This means that the variables that significantly determine the variation in the concentration of trace metals are similar despite the geographic distance between sites $(40 \mathrm{~km})$. This variation is strongly correlated to the origin of the measured elements, which corresponds to that predicted for this study and demonstrated in previous works.

Ordination biplots display a marked negative correlation between $\mathrm{Zn}$ and $\mathrm{Cu}$ elements and $\mathrm{Al}, \mathrm{Fe}$ and $\mathrm{Mn}$, indicated for the 180 angle between variables (Fig. 2). $\mathrm{Ni}$ and $\mathrm{Pb}$ elements were associated 
Table 4: Analysis of variance of the set of data in two sampling sites showing the difference of each element.

\begin{tabular}{|c|c|c|c|c|c|}
\hline Source & $\begin{array}{l}\text { Degrees of } \\
\text { freedom }\end{array}$ & $\begin{array}{c}\text { Sum } \\
\text { of squares }\end{array}$ & Mean square & F value & $\operatorname{Pr}>F^{*}$ \\
\hline \multicolumn{6}{|l|}{$\mathrm{pH}$} \\
\hline Model & 26 & 38.9983 & 1.4999 & 3.48 & 0.0013 \\
\hline $\mathrm{pH}$ treatment & 1 & 6.8912 & 6.8912 & 15.97 & 0.0005 \\
\hline Repetition & 25 & 32.1070 & 1.2843 & 2.98 & 0.0042 \\
\hline Error & 25 & 10.7886 & 0.4315 & & \\
\hline Corrected total & 51 & 49.7869 & & & \\
\hline \multicolumn{6}{|l|}{$\mathrm{Al}$} \\
\hline Model & 26 & 3920.6119 & 150.7928 & 4.60 & 0.0001 \\
\hline $\mathrm{pH}$ treatment & 1 & 1231.4289 & 1231.4289 & 37.53 & $<0.0001$ \\
\hline Repetition & 25 & 2689.1830 & 107.5673 & 3.28 & 0.0021 \\
\hline Error & 25 & 820.2025 & 32.8081 & & \\
\hline \multicolumn{5}{|l|}{$\mathrm{Fe}$} & \\
\hline Model & 26 & 2344.1357 & 90.1591 & 4.37 & 0.0002 \\
\hline $\mathrm{pH}$ treatment & 1 & 1034.3632 & 1034.3632 & 50.13 & $<0.0001$ \\
\hline Repetition & 25 & 1309.7725 & 52.3909 & 2.54 & 0.0117 \\
\hline Error & 25 & 515.8154 & 20.6326 & & \\
\hline Corrected total & 51 & 2859.9511 & & & \\
\hline \multicolumn{6}{|l|}{$\mathrm{Mn}$} \\
\hline Model & 26 & 771.1428 & 29.6594 & 3.32 & 0.0019 \\
\hline $\mathrm{pH}$ treatment & 1 & 153.3556 & 153.3556 & 17.15 & 0.0003 \\
\hline Repetition & 25 & 617.7872 & 24.7115 & 2.76 & 0.0069 \\
\hline Error & 25 & 223.6091 & 8.9444 & & \\
\hline Corrected total & 51 & 994.7519 & & & \\
\hline \multicolumn{6}{|l|}{$\mathrm{Cu}$} \\
\hline Model & 26 & 4446.8669 & 171.0333 & 1.67 & 0.1010 \\
\hline $\mathrm{pH}$ treatment & 1 & 504.7546 & 504.7546 & 4.94 & 0.0355 \\
\hline Repetition & 25 & 3942.1123 & 157.6845 & 1.54 & 0.1425 \\
\hline Error & 25 & 2554.9212 & 102.1968 & & \\
\hline Corrected total & 51 & 7001.7881 & & & \\
\hline \multicolumn{6}{|l|}{$\mathrm{Zn}$} \\
\hline Model & 26 & 12744.5563 & 490.1752 & 2.50 & 0.0124 \\
\hline $\mathrm{pH}$ treatment & 1 & 319.8704 & 319.8704 & 1.63 & 0.2132 \\
\hline Repetition & 25 & 12424.6859 & 496.9874 & 2.54 & 0.0118 \\
\hline Error & 25 & 4900.5377 & 196.0215 & & \\
\hline Corrected total & 51 & 17645.0940 & & & \\
\hline \multicolumn{6}{|l|}{$\mathrm{Pb}$} \\
\hline Model & 26 & 608.8539 & 23.4175 & 6.00 & $<0.0001$ \\
\hline $\mathrm{pH}$ treatment & 1 & 365.7532 & 365.7532 & 93.72 & $<0.0001$ \\
\hline Repetition & 25 & 243.1006 & 9.7240 & 2.49 & 0.0131 \\
\hline Error & 25 & 97.5652 & 3.9026 & & \\
\hline Corrected total & 51 & 706.4191 & & & \\
\hline
\end{tabular}


Table 4: (Continued)

\begin{tabular}{lccrrr}
\hline Source & $\begin{array}{c}\text { Degrees of } \\
\text { freedom }\end{array}$ & $\begin{array}{c}\text { Sum } \\
\text { of squares }\end{array}$ & Mean square & F value & Pr $>\mathrm{F}^{*}$ \\
\hline $\mathrm{Ni}$ & & & & & \\
Model & 26 & 477.2361 & 18.3552 & 3.21 & 0.0023 \\
$\mathrm{pH}$ treatment & 1 & 215.4251 & 215.4251 & 37.69 & $<0.0001$ \\
Repetition & 25 & 261.8109 & 10.4724 & 1.83 & 0.0684 \\
Corrected total & 51 & 620.1122 & & & \\
\hline
\end{tabular}

*If $\operatorname{Pr}>\mathrm{F}$ is greater than 0.05 then $\mathrm{F}$ is not significant.

Table 5: Mean comparison among different elements and $\mathrm{pH}$, data obtained from June 1 to October 1 , 2004.

\begin{tabular}{lrrll}
\hline & Tukey grouping & Mean & N & \multicolumn{1}{c}{ Treatment } \\
\hline $\mathrm{pH}$ & $\mathrm{A}$ & 5.37 & 26 & Isla del Carmen \\
& $\mathrm{B}$ & 4.64 & 26 & San Antonio-Cardenas \\
$\mathrm{Al}$ & $\mathrm{A}$ & 28.77 & 26 & Isla del Carmen \\
& $\mathrm{B}$ & 19.04 & 26 & San Antonio-Cardenas \\
$\mathrm{Fe}$ & $\mathrm{A}$ & 19.66 & 26 & Isla del Carmen \\
& $\mathrm{B}$ & 10.74 & 26 & San Antonio-Cardenas \\
$\mathrm{Mn}$ & $\mathrm{A}$ & 10.18 & 26 & Isla del Carmen \\
& $\mathrm{B}$ & 6.74 & 26 & San Antonio-Cardenas \\
$\mathrm{Cu}$ & $\mathrm{A}$ & 30.90 & 26 & Isla del Carmen \\
& $\mathrm{B}$ & 24.67 & 26 & San Antonio-Cardenas \\
$\mathrm{Zn}$ & $\mathrm{A}$ & 44.81 & 26 & Isla del Carmen \\
& $\mathrm{A}$ & 39.85 & 26 & San Antonio-Cardenas \\
$\mathrm{Pb}$ & $\mathrm{A}$ & 10.18 & 26 & Isla del Carmen \\
& $\mathrm{B}$ & 4.88 & 26 & San Antonio-Cardenas \\
$\mathrm{Ni}$ & $\mathrm{A}$ & 10.62 & 26 & Isla del Carmen \\
& $\mathrm{B}$ & 6.55 & 26 & San Antonio-Cardenas \\
\hline
\end{tabular}

Note: Means with the same letter are not significantly different.

with the second factor; however, the contribution of these elements to the total inertia was low. Ordination biplot combining the two sites showed a similar distribution of elements with intra-site variation (Fig. 3). From the total variation of the relationship among elements of the survey sites, $90 \%$ was explained for the first principal component ( $\mathrm{PC} 1)$, which means that there is a strong influence of the inter-variables correlation. PC2 adds only $6 \%$ to the total variation (Table 6). The remaining eight principal components calculated added a negligible variation to the overall. The scores for the variables at San Antonio-Cardenas and Isla del Carmen were remarkably similar, which indicates a common effect of wet deposition and sources of the elements. Considering that samples were taken simultaneously at both sites, and sites are only $40 \mathrm{~km}$ apart, a widespread environmental effect can be assumed. 


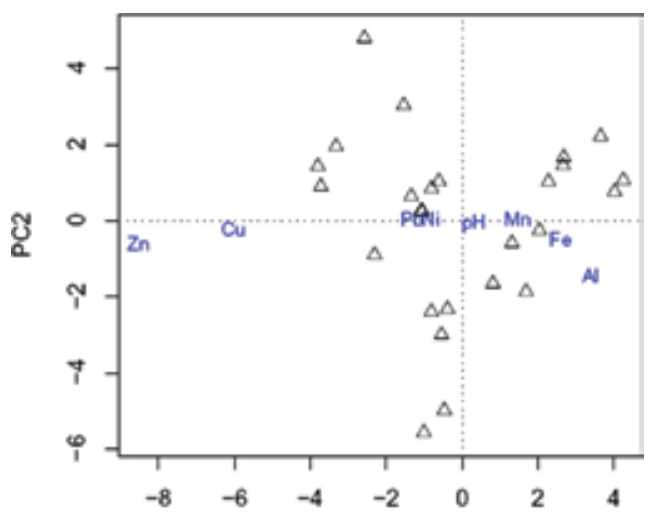

(a)

PC1

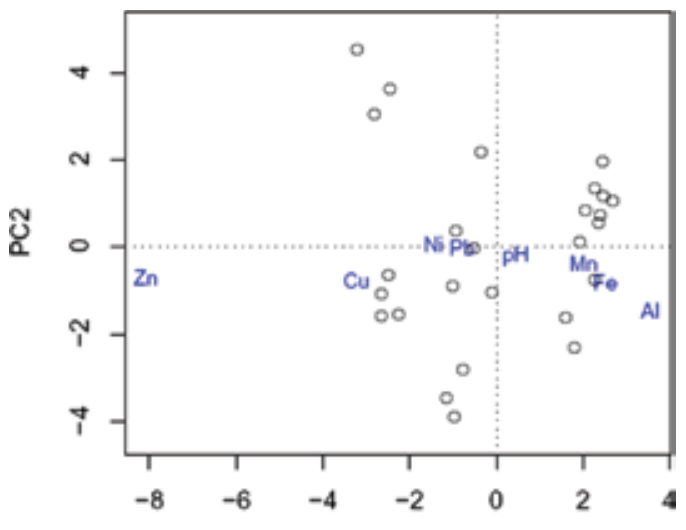

(b)

PC1

Figure 2: Principal component analysis: Ordination biplot of 26 trace element samples for Isla del Carmen (a) and San Antonio-Cardenas (b). Trace elements are represented by their symbols.

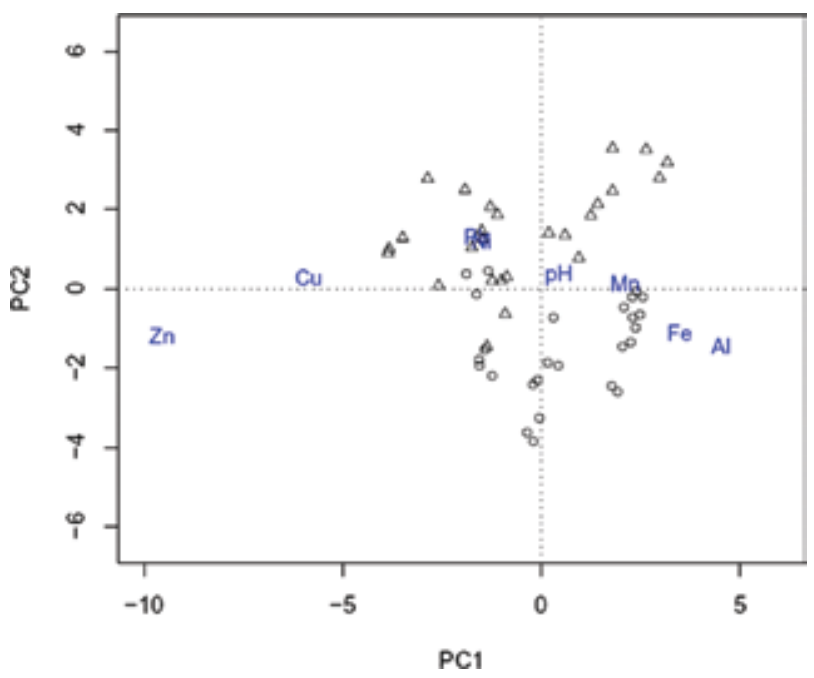

Figure 3: Principal component analysis: Ordination biplot of 52 samples with respect to the axes I and II. $\Delta=$ Isla del Carmen and $\mathrm{o}=$ San Antonio-Cardenas.

The higher standard deviation of the values of $\mathrm{Zn}$ along the survey was evident, which is indicated for the length of projection of the element from the center of the diagram at Figs 2 and 3. On the other hand, $\mathrm{pH}, \mathrm{Pb}$ and $\mathrm{Ni}$, showed relatively uniform values for both survey sites and dates. In comparison between sites a distribution pattern of the survey points was observed; the points corresponding to San Antonio-Cardenas were clearly located along the diagonal line formed by $\mathrm{Al}$, $\mathrm{Fe}, \mathrm{Mn}$ in the biplot diagram, which means that in Isla del Carmen (Table 6), excepting for Mn, all trace elements showed EF greater than 1. This implies that Mn had its origin in the crustal, whereas the rest of the trace elements had an origin different from the crustal, probably in anthropogenic 
Table 6: Proportional contribution of the first two principal components (PCs) to the total estimated variation in data and the scores expressed for the measured elements.

\begin{tabular}{|c|c|c|c|c|c|c|}
\hline \multicolumn{3}{|c|}{$\begin{array}{l}\text { San Antonio-Cardenas } \\
\text { and Isla del Carmen }\end{array}$} & \multicolumn{2}{|c|}{ San Antonio-Cardenas } & \multicolumn{2}{|c|}{ Isla del Carmen } \\
\hline & $\mathrm{PC}$ & $\mathrm{PC}$ & $\mathrm{PC} 1$ & PC2 & PC1 & PC2 \\
\hline Total & $90 \%$ & $6 \%$ & $92 \%$ & $4 \%$ & $96 \%$ & $3 \%$ \\
\hline $\mathrm{pH}$ & 0.4566 & -0.1483 & 0.4473 & -0.2020 & 0.3073 & -0.0633 \\
\hline $\mathrm{Al}$ & 4.5460 & -2.0073 & 3.5642 & -1.4644 & 3.3791 & -1.4530 \\
\hline $\mathrm{Fe}$ & 3.4896 & -1.6515 & 2.5008 & -0.8105 & 2.5880 & -0.4963 \\
\hline $\mathrm{Mn}$ & 2.1179 & -0.4087 & 2.0179 & -0.3679 & 1.4619 & 0.0529 \\
\hline $\mathrm{Cu}$ & -5.8480 & -0.2741 & -3.2312 & -0.7827 & -6.0230 & -0.2073 \\
\hline $\mathrm{Zn}$ & -9.5462 & -1.7266 & -8.0866 & -0.6929 & -8.5170 & -0.5856 \\
\hline $\mathrm{Pb}$ & -1.6144 & 0.7816 & -0.7908 & -0.0272 & -1.3195 & 0.0493 \\
\hline $\mathrm{Ni}$ & -1.5030 & 0.6667 & -1.4500 & 0.0155 & -0.8294 & 0.0429 \\
\hline
\end{tabular}
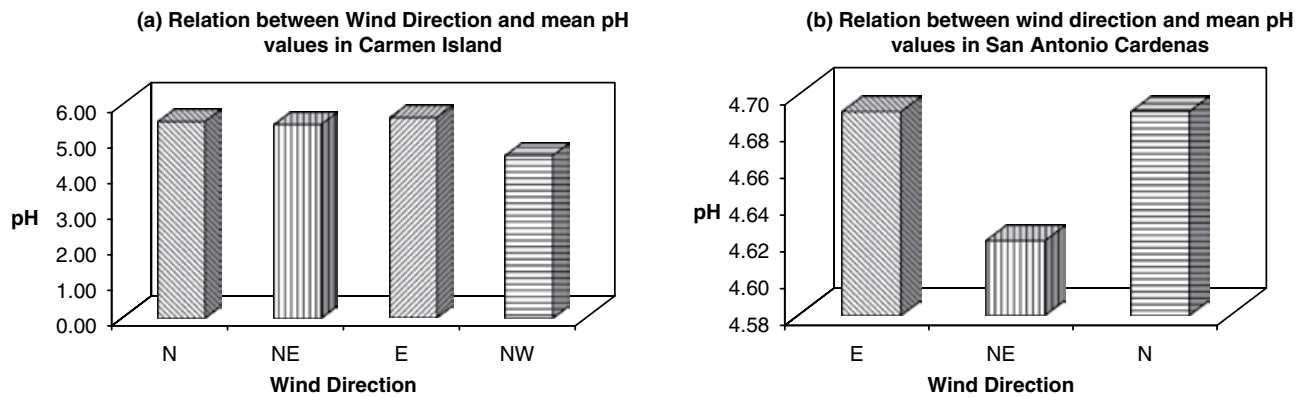

Figure 4: Relation between air masses origin and $\mathrm{pH}$ values in the rainwater collected in (a) Isla del Carmen, and (b) San Antonio-Cardenas.

sources. Fe showed an EF slightly greater than unity and the crustal fraction was $88 \%$, indicating a nonsignificant enrichment; therefore, we can conclude that this element had a geochemical source.

\subsection{Analysis of trajectories}

To identify possible sources different from marine aerosol and crustal that could contribute to the rainwater mineralization process in this study, backward trajectories were computed using Hysplit Model (NOAA) $48 \mathrm{~h}$ before each rain event at three different heights (0,1000 and $2000 \mathrm{~m})$.

According to these trajectories, the origin of the air masses for the rain events was traced. Prevailing winds in Isla del Carmen blew from NE during all sampling campaign as is expected during the summer, when the region is under the influence of tropical maritime air. However, sometimes, when the air blew from $\mathrm{NW}$, higher levels of $\mathrm{Cu}, \mathrm{Zn}, \mathrm{Pb}$ and $\mathrm{Ni}$ were observed, indicating a possible contribution from the offshore platforms located at $60 \mathrm{~km}$ at NW from Isla del Carmen (Fig. 5a). Likewise, mean $\mathrm{pH}$ values were lower when the air masses came from NW (Fig. 4a). Whereas mean levels of $\mathrm{Al}, \mathrm{Fe}$ and $\mathrm{Mn}$ where higher when the air blew from $\mathrm{E}$, it suggests a possible continental contribution of crust from Yucatan Peninsula located at E from Isla del Carmen (Fig. 5a). 

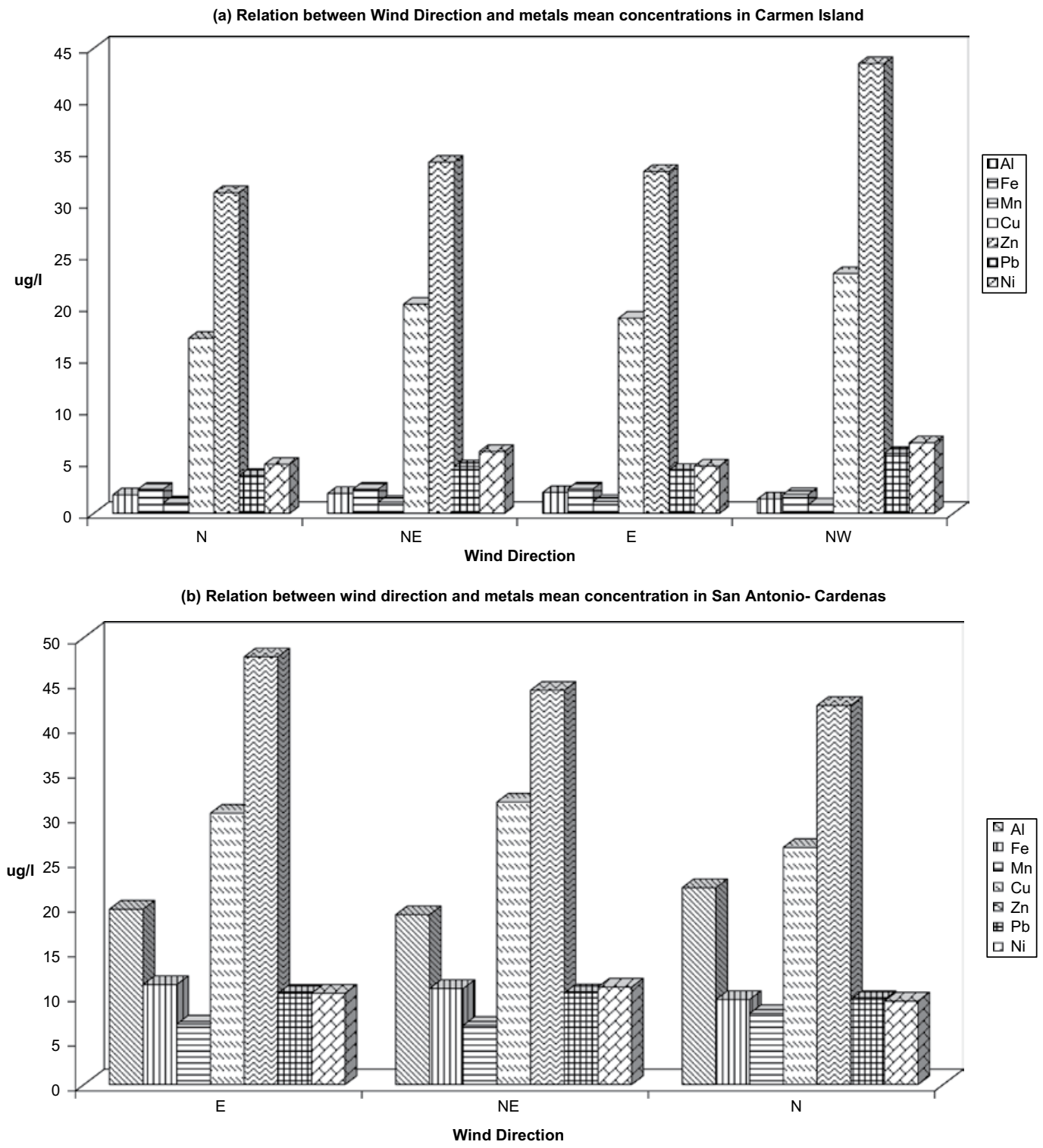

Figure 5: Relation between air masses origin and mean levels of trace metals in the rainwater collected in (a) Isla del Carmen, and (b) San Antonio-Cardenas.

On the other hand, in San Antonio-Cardenas, the prevailing winds came from NE. This suggests that this site was under the influence of local anthropogenic sources located at NE from sampling site: the sour gas recompression plant in Atasta, where gases and particles released could produce secondary aerosols, which probably were up taken to the rainwater by heterogeneous nucleation, rain-out or wash-out processes. In Fig. 4b, it can be observed that $\mathrm{pH}$ mean values were lower when air masses came from NE. In addition, mean levels of $\mathrm{Cu}, \mathrm{Zn}, \mathrm{Pb}$ and $\mathrm{Ni}$ were higher when the 
Table 7: Enrichment factors relative to the crustal for both sampling sites.

\begin{tabular}{lcc}
\hline Element & EF in San Antonio-Cardenas & EF in Isla del Carmen \\
\hline $\mathrm{Fe}$ & 0.9 & 1.1 \\
$\mathrm{Mn}$ & 0.9 & 0.9 \\
$\mathrm{Zn}$ & 3.2 & 1.9 \\
$\mathrm{Cu}$ & 2.9 & 1.6 \\
$\mathrm{~Pb}$ & 4.5 & 1.4 \\
$\mathrm{Ni}$ & 4.4 & 1.8 \\
\hline
\end{tabular}

air blew from $\mathrm{E}$ to $\mathrm{NE}$, indicating a possible contribution from the sour gas recompression plant, located at NE from San Antonio-Cardenas (Fig. 5b). On the other hand, mean concentration of Fe was higher when the air masses blew from E, suggesting a significant contribution from Yucatan Peninsula located at E from San Antonio-Cardenas (Fig. 5b).

However, vehicular emissions could be an additional source that contributed with trace elements to the rainwater chemical composition, due to the fact that the sampling site in Isla del Carmen is located on the main avenue of the city, whereas the sampling site in San Antonio-Cardenas is located near to 180 federal highway from Villahermosa to Isla del Carmen.

\subsection{Enrichment factors}

To determine the possible geochemical and anthropogenic sources of elements present in precipitation, the enrichment factors relative to the crustal (EF) and the crustal fraction for each trace element were calculated, according to the approach proposed by Ahmed et al. [38] (see Table 7). Cerón et al. [14] concluded that in these two sites (Isla del Carmen and San Antonio-Cardenas), $\mathrm{Na}^{+}, \mathrm{Mg}^{2+}$ and $\mathrm{Cl}^{-}$had an origin that was typically marine (EF close to 1 ), whereas $\mathrm{K}^{+}, \mathrm{Ca}^{2+}$ and $\mathrm{SO}_{4}{ }^{2-}$ were enriched elements and they showed a significant excess $(\mathrm{EF}>1)$; this means that other sources were contributing notably to their levels present in rainwater.

Due to their nature, $\mathrm{Al}$ in rainwater has its origin completely from the crustal, and often shows an EF closer to unity. On the other hand, high temperature processes (smelting, combustion and volcanic activity) are usually common sources of metallic particles $(\mathrm{Cu}, \mathrm{Cd}, \mathrm{Zn}, \mathrm{Pb}$ and $\mathrm{Ni}$ ) in the atmosphere, with an origin different from the crustal [3, 39]. For this reason, trace elements such as $\mathrm{Pb}, \mathrm{Zn}$ and $\mathrm{Cr}$ are often enriched [40]. $\mathrm{EF}$ for $\mathrm{Zn}, \mathrm{Cu}, \mathrm{Pb}$ and $\mathrm{Ni}$ in the rainwater collected in San Antonio-Cardenas showed values greater than unity (Table 7); therefore, it can be inferred that these elements had an origin different from the crustal, probably in anthropogenic sources. On the other hand, Fe and Mn have an EF lower than unity, with crustal fractions closer to $100 \%$, suggesting that they had an exclusive origin in soil particles.

\subsection{Comparison of trace metal concentrations found in this research with other studies}

In Tables 8-10, mean trace metal concentrations for rural, remote and urban locations, respectively, are compared with the results of this study.

In both sites considered by this research, $\mathrm{Al}$ showed a mean concentration lower than those reported in rural sites like Rancho Viejo, Mexico and Northern Jordan. In Isla del Carmen, Mn 


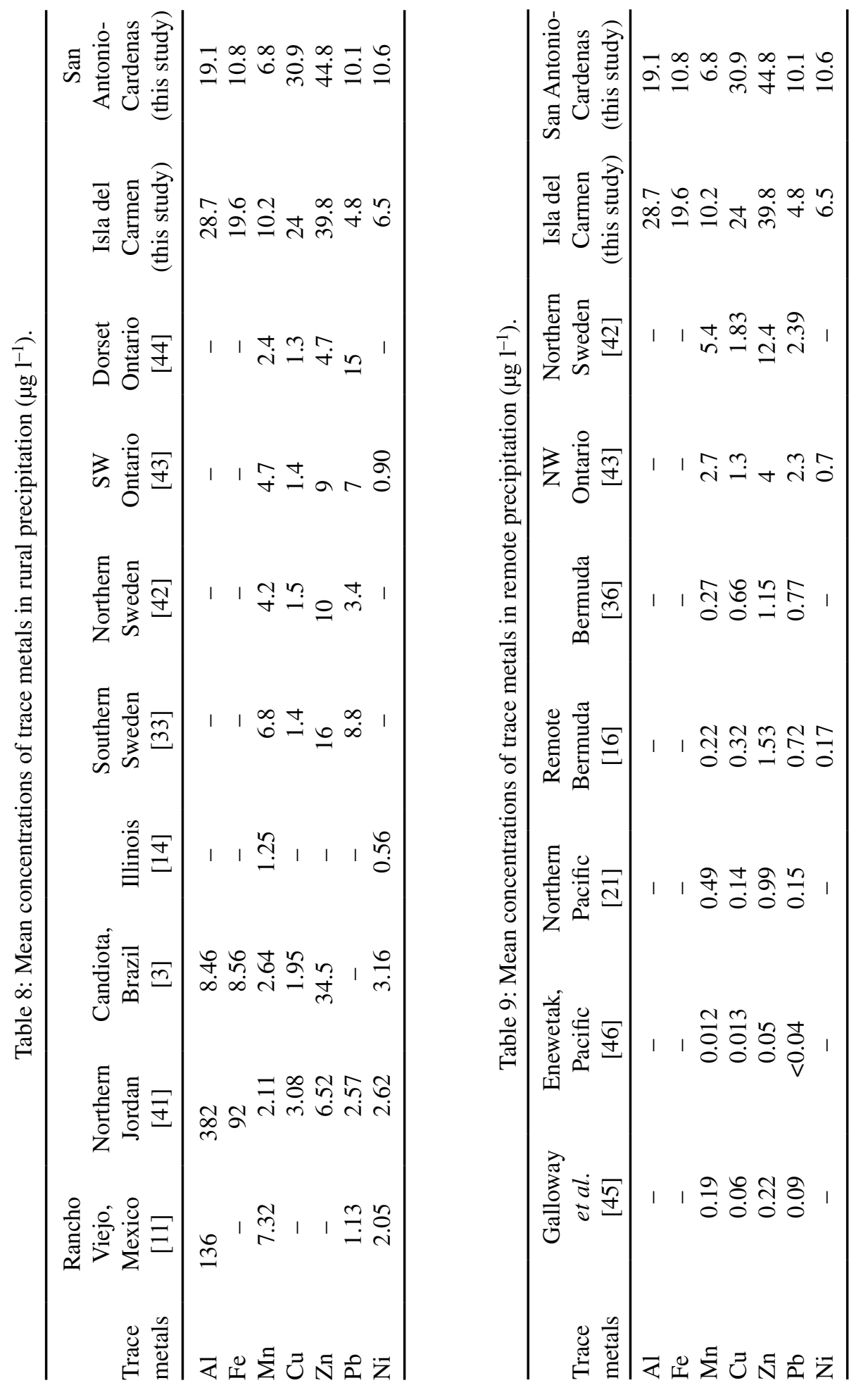


Table 10: Mean concentrations of trace metals in urban precipitation $\left(\mu \mathrm{g}^{-1}\right)$.

\begin{tabular}{lccccc}
\hline $\begin{array}{l}\text { Trace } \\
\text { metals }\end{array}$ & $\begin{array}{c}\text { Athens, Greece } \\
{[1]}\end{array}$ & $\begin{array}{c}\text { Acegua, Brazil } \\
{[3]}\end{array}$ & $\begin{array}{c}\text { Bage, Brazil } \\
{[3]}\end{array}$ & $\begin{array}{c}\text { Isla del Carmen } \\
\text { (this study) }\end{array}$ & $\begin{array}{c}\text { San Antonio- } \\
\text { Cardenas } \\
\text { (this study) }\end{array}$ \\
\hline $\mathrm{Al}$ & 5.8 & 5.6 & 10 & 28.7 & 19.1 \\
$\mathrm{Fe}$ & 4.3 & 11 & 8.3 & 19.6 & 10.8 \\
$\mathrm{Mn}$ & 3.6 & 2.9 & 2.2 & 10.2 & 6.8 \\
$\mathrm{Cu}$ & 15.4 & 1.4 & 2 & 24 & 30.9 \\
$\mathrm{Zn}$ & 33.4 & 17 & 28 & 39.8 & 44.8 \\
$\mathrm{~Pb}$ & 0.8 & - & - & 4.8 & 10.1 \\
$\mathrm{Ni}$ & 4.1 & 1.7 & 1.4 & 6.5 & 10.6 \\
\hline
\end{tabular}

showed a mean concentration slightly higher than those found in rural sites, whereas in San AntonioCardenas, the mean value of $\mathrm{Mn}$ was within the range reported for rural sites. $\mathrm{Pb}$ mean concentration in both sites was according to those reported in other rural sites.

On the other hand, mean concentration of $\mathrm{Cu}$ was higher than those reported in rural sites. $\mathrm{Zn}$ showed a mean concentration similar to that found in Candiota, Brazil, whereas Ni showed a mean value slightly higher than those reported for rural locations (Table 8). It can be observed from Table 9 that all trace metals in this study showed mean concentrations higher than those reported for remote locations. On the other hand, from Table 10, it can be observed that Al showed mean concentrations higher than those reported in other urban sites. Mean concentrations for $\mathrm{Fe}$ and $\mathrm{Mn}$ were slightly higher than those reported for urban sites, whereas mean values of $\mathrm{Zn}$ and Ni were similar to those observed in Athens City.

\section{CONCLUSION}

The study of the chemical composition of the rainwater (ions and trace elements levels) in San Antonio-Cardenas and Isla del Carmen was important to establish a data base of wet deposition behaviour in these two coastal sites located in Campeche, Mexico. In a previous paper [14], the ionic abundance was reported and their origin was discussed. $\mathrm{Na}^{+}$and $\mathrm{Ca}^{2+}$ were the most abundant cations, whereas $\mathrm{Cl}^{-}$and $\mathrm{SO}_{4}{ }^{2-}$ were the most abundant anions. High sulfate levels in both sites are comparable to that found in sites with anthropogenic influence. In this paper, measurements of trace elements in these two sites and source apportionment were discussed. In both sampling sites, significant fractions of $\mathrm{Al}, \mathrm{Fe}$ and $\mathrm{Mn}$ were found in an insoluble form; these trace metals did not show an enrichment and correlated in a significant way to each other. It suggests that these elements had common sources, probably soil particles or crustal. It can be concluded that the influence of crustal on rainwater mineralization process was evident in both sites. A relationship between $\mathrm{pH}$ values greater than 5 and the elements whose main origin is the crustal ( $\mathrm{Al}, \mathrm{Fe}$ and $\mathrm{Mn}$ ) was found.

On the other hand, in both sampling sites, a significant fraction of $\mathrm{Cu}, \mathrm{Pb}, \mathrm{Zn}$ and $\mathrm{Ni}$ was found in dissolved form; these elements showed an EF greater than 1 and correlated in a significant way to each other. It suggests that these trace elements were enriched and had a common origin (probably anthropogenic sources). Finally, the enrichment for $\mathrm{Cu}, \mathrm{Pb}, \mathrm{Zn}$ and $\mathrm{Ni}$ was greater in San AntonioCardenas than in Isla del Carmen, due to prevailing winds in San Antonio-Cardenas (winds came from NE) because this site was under the influence of local anthropogenic sources (probably, the recompression plant of sour gas at Atasta located at NE from San Antonio-Cardenas). In addition, contribution of vehicular sources in both sampling sites could be important because San Antonio- 
Cardenas is located at $300 \mathrm{~m}$ from federal highway 180, and the sampling site in Isla del Carmen was located inside the facilities of Universidad Autónoma del Carmen, that is a place with a high density of vehicular traffic. However, an intensive campaign of rainwater sampling could help to get a better understanding about trace element deposition in this region. Additionally, to establish a reliable flux pattern, more wind data from soundings at different heights are required.

\section{REFERENCES}

[1] Kanellopoulou, E.A., Determination of heavy metals in wet deposition of Athens. Global Nest: The Int. J., 3, pp. 45-50, 2001.

[2] Weisel, C.P., Duce, R.A., Fasching, J.L. \& Heaton, R.W., Estimates of the transport of trace metals from the ocean to the atmosphere. J. Geophys. Res., 89, pp. 11607-11618, 1984. doi:10.1029/JD089iD07p11607

[3] Migliavacca, D., Texeira, E.C., Pires, M. \& Fachel, J., Study of chemical elements in atmospheric precipitation in South Brazil. Atmospheric Environment, 38, pp. 1641-1656, 2004. doi:10.1016/j.atmosenv.2003.11.040

[4] Colin, J.L. \& Jaffrezo, J.L., Solubility of major species in precipitation: factors of variation. Atmospheric Environment, 3, pp. 537-544, 1990.

[5] Avila, A. \& Rodrigo, A., Trace metal fluxes in bulk deposition, troughfall and stemflow at two evergreen oak stands in NE Spain subject to different exposure to the industrial environment. Atmospheric Environment, 38, pp. 171-180, 2004. doi:10.1016/j.atmosenv.2003.09.067

[6] Hlavay, J., Polyak, K., Molnar, A. \& Mëszaros, E., Determination of the distribution of elements as a function of particle size in aerosol samples by sequential leaching. Analyst, 123, p. 859, 1998. doi:10.1039/a708117k

[7] Lim, B. \& Jickells, T.D., Dissolved, particulate and acid leachable trace metals concentrations in North Atlantic precipitation collected on the Global Change Expedition. Global Biogeo- chemical Cycles, 4, pp. 445-458, 1990. doi:10.1029/GB004i004p00445

[8] Wong, C.S., Li, X.D., Zhang, G., Qi, S.H. \& Peng, X.Z., Atmospheric deposition of heavy metals in the Pearl River Delta, China. Atmospheric Environment, 37, pp. 767-776, 2003. doi:10.1016/S1352-2310(02)00929-9

[9] Sequeira, R., On the solubility of some natural minerals in atmospheric precipitation. Atmospheric Environment, 22, pp. 369-374, 1988. doi:10.1016/0004-6981(88)90042-X

[10] Arimoto, R., Duce, R.A., Ray, B.J., Hewitt, A.D. \& Williams, J., Trace elements in the atmosphere of American Samoa: concentrations and deposition to the Tropical South Pacific. J. Geophys. Res., 92, pp. 8465-8479, 1987. doi:10.1029/JD092iD07p08465

[11] García, R., Torres, M.C., Padilla, H., Belmont, R., Azpra, E., Arcega-Cabrera, F. \& Báez, A., Measurement of chemical elements in rain from Rancho Viejo, a rural wooded area in the State of Mexico, Mexico. Atmospheric Environment, 40, pp. 6088-6100, 2006. doi:10.1016/j. atmosenv.2006.05.048

[12] Vongh, R.J., Hansson, H.C., Ross, H.B., Covert, D.S. \& Charlson, R.J., Simultaneous observations of rainwater and aerosol chemistry at a remote mid-latitude site. Symposium on Acid Rain-1. Sources and atmospheric processes, presented before the Division of Petroleum Chemistry, Inc. American Chemical Society Meeting, 13-18 April 1986.

[13] Spokes, L.J. \& Jickells, T.D., Speciation of metals in the atmosphere. In: Chemical Speciation in the Environment, eds A.M. Ure, C.M. Davidson, Blackie: London, pp. 137-168, 1995.

[14] Cerón, R.M., Cerón, J.G. \& Muriel, M., Influence of geochemical and anthropogenic sources on rainwater chemical composition in two coastal sites impacted by the gas and oil industry in 
Campeche Mexico. In: Environmental Problems in Coastal Regions VI, WIT transactions on Ecology and the Environment, vol. 88, pp. 419-428, 2006.

[15] Halstead, M.J., Cunningham, R.G. \& Hunter, K.A., Wet deposition of trace metals to a remote site in Fiordland, New Zeland. Atmospheric Environment, 34, pp. 665-676, 2000. doi:10.1016/ S1352-2310(99)00185-5

[16] Jickells, T.D., Knap, A.H. \& Church, T.M., Trace metals in Bermuda rainwater, J. Geophys. Res., 89, pp. 1423-1428, 1984. doi:10.1029/JD089iD01p01423

[17] Lindberg, S.E. \& Turner, R.R., Trace metals in rain at forested sites in the Eastern Unites States. Proceedings, International Conference on Heavy Metals in the Environment. CEP Publishers: Edinburgh, UK, pp. 107-114, 1983.

[18] Basak, B. \& Alagha, O., The chemical composition of rainwater over Büyükcekmece Lake, Istambul. Atmospheric Research, 71, pp. 275-288, 2004. doi:10.1016/j.atmosres.2004.07.001

[19] García, E., Carta de climas. Dirección de planeación. Comisión de estudios del territorio nacional y Planeación. México, 1970.

[20] Smirniourdi, V., Thomaidis, M.S., Piperaki, E.A. \& Siskos, P.A., Determination of trace metals in wet and dust deposition in Greece. Fres. Environ. Bul., 7, pp. 85-90, 1998.

[21] Duce, R.A., Liss, P.S., Merrill, J.T., Atlas, E.L., Buat-Menard, P., Miller, J.M., Prospero, J.M., Arimoto, R., Church, T.M., Ellis, W., Galloway, J.N., Hansen, L., Jickells, T.D., Knap, A.H., Reinhardt, K.H., Schneider, B., Soudine, A., Tokos, J.J., Tsunogai, S., Wollast, R. 2006 Zhou, M., The atmospheric input of trace species to the world ocean. Global Biogeochemical Cycles, 5, pp. 193-259, 1991. doi:10.1029/91GB01778

[22] IMP, Diagnóstico de la Calidad Ambiental en la Zona Marina y Costera de PEP, Fase I. Gerencia de Seguridad Industrial y Protección Ambiental. PEMEX Exploración y producción. Región Marina Suroeste, 1998.

[23] Ahlers, W.W., Reid, M.R., Kim, J.P. \& Hunter, K.A., Contamination-free sample collection and handling protocols for trace elements in natural fresh waters. Australian Journal of Marine and Freshwater Research, 41, pp. 713-720, 1990. doi:10.1071/MF9900713

[24] Taylor, S.R. \& McLennan, S.M., In: The Continental Crust, its Composition and Evolution, Balckwells: Oxford, 1985.

[25] USEPA, Method 7020. Aluminium (Atomic Absorption, Direct Aspiration). Methods for chemical analysis of water and wastes. U.S. Environmental protection Agency. Office of Research and Development, vol. I, Section A, Chapter 3-Inorganic analytes, 1998.

[26] USEPA, Method 7211. Copper (Atomic Absorption, Furnace Technique). Methods for chemical analysis of water and wastes. U.S. Environmental protection Agency. Office of Research and Development, vol. I, Section A, Chapter 3-Inorganic analytes, 1998.

[27] USEPA, Method 7251. Nickel (Atomic Absorption, Furnace Technique). Methods for chemical analysis of water and wastes. U.S. Environmental protection Agency. Office of Research and Development, vol. I, Section A, Chapter 3-Inorganic analytes, 1998.

[28] USEPA, Method 7381. Iron (Atomic Absorption, Furnace Technique). Methods for chemical analysis of water and wastes. U.S. Environmental protection Agency. Office of Research and Development, vol. I, Section A, Chapter 3-Inorganic analytes, 1998.

[29] USEPA, Method 7951. Zinc (Atomic Absorption, Furnace Technique). Methods for chemical analysis of water and wastes. U.S. Environmental protection Agency. Office of Research and Development, vol. I, Section A, Chapter 3-Inorganic analytes, 1998.

[30] USEPA, Method 7461. Manganese (Atomic Absorption, Furnace Technique). Methods for chemical analysis of water and wastes. U.S. Environmental protection Agency. Office of Research and Development, vol. I, Section A, Chapter 3-Inorganic analytes, 1998. 
[31] SCFI, NMX-AA-008-2000. Aguas. Determinación de pH. Método potenciometrico, 2000.

[32] SCFI, NMX-AA-051-SCFI-2001. Análisis de agua-Determinación de metales por absorción atómica en aguas naturales, potables, residuales y residuales tratadas. Método de prueba, 2001.

[33] Ross, H.B., Ph.D. Thesis, Department of Meteorology, University of Stockholm, Sweden. 1986b.

[34] SAS Institute Inc. SAS/STAT, Guide for personal computers. Version 8. United States of America, 1998.

[35] Galloway, J.N., Thornton, J.D., Norton, S.A., Volchok, H.L. \& McLean, R.A.N., Trace metals in atmospheric deposition: a review and assessment. Atmospheric Environment, 16, pp. 1677-1700, 1982. doi:10.1016/0004-6981(82)90262-1

[36] Church, T.M., Tramontano, J.M., Scudlark, J.R., Jickells, T.D., Tokos, J.J., Knap, A.H. \& Galloway, J.N., The wet deposition of trace metals to the Western Atlantic Ocean at the Mid-Atlantic coast and on Bermuda. Atmospheric Environment, 18, pp. 2657-2664, 1984. doi:10.1016/0004-6981(84)90330-5

[37] Kim, G., Scudlark, J.R. \& Church, T.M., Atmospheric wet deposition of trace elements to Chesapeake and Delaware Bays. Atmospheric Environment, 34, pp. 3437-3444, 2000. doi:10.1016/ S1352-2310(99)00371-4

[38] Ahmed, A.F.M., Singh, R.P. \& Elmubarak, A.H., Chemistry of atmospheric precipitation at the western Arabian Gulf Coast. Atmospheric Environment, 24 A, pp. 2927-2934, 1990.

[39] Nriagu, J.O. \& Pacina, J.M., Quantitative assessment of worldwide contamination of air, water and soils by trace metals. Nature, 333, pp. 134-139, 1988. doi:10.1038/333134a0

[40] Berg, T., Royset, O. \& Steinnes, E., Trace elements in atmospheric precipitation at Norwegian background stations (1989-1990) measured by ICP-MS. Atmospheric Environment, 28, pp. 3519-3536, 1994. doi:10.1016/1352-2310(94)90009-4

[41] Al-Momani, I.F., Trace elements in atmospheric precipitation at Northern Jordan measured by ICP-MS: acidity and possible sources. Atmospheric Environment, 37, pp. 4507-4515, 2003. doi:10.1016/S1352-2310(03)00562-4

[42] Ross, H.B., The importance of reducing sample contamination in routine monitoring of trace metals in atmospheric precipitation. Atmospheric Environment, 20, pp. 401-405, 1986. doi:10.1016/0004-6981(86)90044-2

[43] OME, Annual statistics of concentration and deposition cumulative precipitation monitoring network. 1983. ARB-087-85-AQM. Ontario Ministry of the Environment. 880 Bay Street, 4th Floor, Toronto, Ontario, Canada M5S 1Z8, 1985.

[44] Barrie, L.A., Lindberg, S.E., Chan, W.H., Ross, H.B., Arimoto, R. \& Church, T.M., On the concentration of trace elements in precipitation. Atmospheric Environment, 21, pp. 1133-1135, 1987. doi:10.1016/0004-6981(87)90240-X

[45] Galloway, J.N., The wet deposition of trace metals to the Western Atlantic Ocean at the Mid-Atlantic coast and on Bermuda. Atmospheric Environment, 18, pp. 2657-2664, 1984. doi:10.1016/0004-6981(84)90330-5

[46] Arimoto, R., Duce, R.A., Ray, B.J. \& Uni, C.K., Atmospheric trace elements at Enewetak Hall-2. Transport to the ocean by wet and dry deposition. J. Goephys. Res., 90, pp. 2391-2408, 1985. doi:10.1029/JD090iD01p02391 